\title{
In memoriam of Professor Leszek Szczepański
}

Professor Leszek Szczepański, PhD (hab.) passed away in Lublin, on 23 January 2019, after a long and serious illness. He was 86 years old.

He was a native resident of Lublin. There, in his beloved city, he spent his childhood, graduated from secondary school, and lived through the German occupation. Between 1951 and 1957, he studied at the medical faculty of the Lublin Medical Academy (today's Medical University of Lublin).

After graduation, he left his home city for a short period (1957-1960) to work in the sanatorium in Połczyn-Zdrój. He also cooperated briefly with the Pomeranian Medical University.

However, he was quick to return to Lublin, where he continued working as a clinician, university lecturer and head of the unit and then Department of Rheumatology until his retirement in 2003. He gradually went through all stages of his academic career: from the degrees of doctor and habilitated doctor of medical sciences up to the title of professor which was conferred on him in 1995. In 1990-1993, he served as the Dean of the Faculty of Medicine, Medical University of Lublin.

Professor Leszek Szczepański was a specialist in internal diseases and rheumatology. He also had a brief spell with cardiology, which he often mentioned in humorous contexts. He was known for telling his students and colleagues: "You must be passionate about your profession", and I believe that this saying was based on his own life experiences. He was a distinguished figure among Polish rheumatologists. Professor Szczepański was involved in a wide range of teaching, scientific, medical, organizational and social (Medical Chamber) initiatives. In the early 1990s, he originated the idea of holding joint scientific and social meetings for rheumatologists from all over Poland in many beautiful parts of the Lublin and Podkarpacie regions (Do you remember the delightful gatherings in Sieniawa, Kazimierz and Krasiczyn?). The idea of regular meetings of rheumatologists has persisted in various forms until the present day, but contemporary conferences are no match to the stimulating scientific atmosphere (it was at that time that the foundations were laid for modern clinical rheumatology with a completely new quality of drugs exhibiting high efficacy in chronic inflammatory joint diseases) and the sense of shared fun created by Professor Szczepański.

The Professor was active as a scientist and a clinician. He systematized in a rational and practical manner problems related to the classification and treatment of pain within the motor system. He was one of the first rheumatologists in Poland to highlight the problem of fibromyalgia secondary to inflammatory and non-inflammatory joint diseases. One of Professor Szczepański's students defended his doctoral dissertation on this subject. The most prevalent diseases of the motor system plaguing contemporary society - including soft tissue rheumatism, osteoarthritis - were topics close to the Professor's heart. No one could surpass him in discussing these problems in a captivating and passionate but competent way during lectures given to students and a wide group of practising rheumatologists. Professor Leszek Szczepański is an author of a number of textbook chapters addressing these problems. He should also be credited with gathering around himself a group of physicians (his one-time students) who were truly fascinated with rheumatology. He supervised a total of 5 doctoral dissertations.

Professor Szczepański ranks among the pioneers - not only in Poland, but also globally - in introducing the treatment with biological drugs into practical clinical rheumatology.

He was involved in the first clinical trials investigating new biological drugs in the therapy of inflammatory joint diseases. Even as late as twenty years ago, this therapeutic modality was approached with considerable reserve.

The Professor's outstanding achievements in this field are best demonstrated by his co-authorship (among the main authors) of papers listed below, published in the most prestigious international journals including the New England Journal of Medicine, Arthritis \& Rheumatology, and Pain Practice [1-8].

For many years, Professor Szczepański held the position of President of the Lublin Branch of the Polish Society of Rheumatology. He was awarded the title of Honorary Member of the Polish Society of Rheumatology, of which he was Vice-President for several years.

Professor Szczepański was also an author of prose. He published his memoirs containing fascinating literary reflections on what he used to call the "rapidly changing world in which he happened to live".

His unique character will be sorely missed.

Our deepest condolences to the Professor's Family and Friends Maria Majdan, Head of the Chair and Department of Rheumatology and Connective Tissue Diseases, Medical University of Lublin, together with a team of Professor's long-time associates 


\section{Selected publications from the Professor's body of work which provided a basis for introducing innovative therapies in rheumatology:}

1. Edwards JC, Szczepanski L, Szechinski J, Filipowicz-Sosnowska A, Emery P, Close DR, Stevens RM, Shaw T. Efficacy of B-cell-targeted therapy with rituximab in patients with rheumatoid arthritis. N Engl J Med 2004; 350: 2572-2811.

2. Emery P, Fleischmann R, Filipowicz-Sosnowska A, Schechtman J, Szczepanski L, Kavanaugh A, Racewicz AJ, van Vollenhoven RF, Li NF, Agarwal S, Hessey EW, Shaw TM; DANCER Study Group. The efficacy and safety of rituximab in patients with active rheumatoid arthritis despite methotrexate treatment: results of a phase IIB randomized, double-blind, placebo-controlled, dose-ranging trial. Arthritis Rheum 2006; 54: 1390-1400.

3. Scheiman JM, Yeomans ND, Talley NJ, Vakil N, Chan FK, Tulassay Z, Rainoldi JL, Szczepanski L, Ung KA, Kleczkowski D, Ahlbom H, Naesdal J, Hawkey C. Prevention of ulcers by esomeprazole in at-risk patients using non-selective NSAIDs and COX-2 inhibitors. Am J Gastroenterol 2006; 101: 701-710.

4. Szczepański L. [Soft tissue rheumatism in erderly]. Pol Arch Med Wewn 2008; 118 (Suppl): 54-58.

5. Vollenhoven RF, Houbiers JG, ButtgereitF,In'tHoutJ, Boers M, LeijS, Kvien TK, Dijkmans BA, Szczepański L, Szombatil, Sierakowski S, Miltenburg AM. The selective estrogen receptor alpha agonist Org 37663 induces estrogenic effects but lacks antirheumatic activity: a phase Ila trial investigating efficacy and safety of Org 37663 in postmenopausal female rheumatoid arthritis patients receiving stable background methotrexate or sulfasalazine. Arthritis Rheum 2010; 62: 351-358.

6. Binsfeld H, Szczepanski L, Waechter S, Richarz U, Sabatowski R. A randomized study to demonstrate noninferiority of once-daily $\operatorname{OROS}\left({ }^{\circledR}\right)$ hydromorphone with twice-daily sustained-release oxycodone for moderate to severe chronic noncancer pain. Pain Pract 2010; 10: 404-415.

7. Richarz U, Waechter S, Sabatowski R, Szczepanski L, Binsfeld H. Sustained safety and efficacy of once-daily hydromorphone extended-release (OROS ${ }^{\circledR}$ hydromorphone ER) compared with twice-daily oxycodone controlled-release over 52 weeks in patients with moderate to severe chronic noncancer pain. Pain Pract 2013; 13: 30-40.

8. Greenwald M, Szczepanski L, Kennedy A, Veenhuizen M, Komocsar WJ, Polasek E, Guerrettaz K, Berclaz PY, Lee C. A 52-week, open-label study evaluating the safety and efficacy of tabalumab, an anti-B-cell-activating factor monoclonal antibody, for rheumatoid arthritis. Arthritis Res Ther 2014; 16: 415. 